\title{
Foodborne Zoonoses Common in Hunted Wild Boars
}

\author{
Maria Fredriksson-Ahomaa $\mathbb{0},{ }^{1}$ Laura London, ${ }^{2}$ Teresa Skrzypczak, ${ }^{3}$ Tuija Kantala, ${ }^{2}$ \\ Ilona Laamanen, ${ }^{2}$ Mia Biström, ${ }^{3}$ Leena Maunula, ${ }^{1}$ and Tuija Gadd ${ }^{2}$ \\ ${ }^{1}$ Department of Food Hygiene and Environmental Health, Faculty of Veterinary Medicine, University of Helsinki, P.O.Box 66, 00014 Helsinki, Finland \\ ${ }^{2}$ Virology Unit, Finnish Food Authority, Helsinki, Finland \\ ${ }^{3}$ Veterinary Bacteriology and Pathology Unit, Finnish Food Authority, Helsinki, Finland
}

\begin{abstract}
The northern European wild boar population has increased during the last decade. Highest wild boar numbers in Finland have been reported in the southeastern part near the Russian border. Wild boars may be infected with several human and animal pathogens. In this study, we investigated the presence of important foodborne pathogens in wild boars hunted in 2016 in Finland using serology, PCR and culturing. Seroprevalence of Salmonella (38\%) and Yersinia (56\%) infections was high in wild boars. Antibodies to hepatitis E virus, Toxoplasma gondii and Brucella were found in 18\%, $9 \%$ and $9 \%$ of the wild boars, respectively. Trichinella antibodies were detected in $1 \%$ of the animals. We recorded no differences in the seroprevalence between males and females. However, Yersinia and T. gondii antibodies were detected significantly more often in adults than in young individuals. Listeria monocytogenes (48\%) and stx-positive Escherichia coli (33\%) determinants were frequently detected in the visceral organs (spleen and kidneys) by PCR. Yersinia pseudotuberculosis $\mathrm{O}: 1$ and L. monocytogenes $2 \mathrm{a}$ and $4 \mathrm{~b}$ were identified by culturing from the PCR-positive samples. Brucella suis biovar 2 was isolated from visceral organs. No African swine fever, classical swine fever or Aujeszky's disease were detected in the wild boars. Our study shows that wild boars are important reservoirs of foodborne pathogens.
\end{abstract}

Keywords: Foodborne pathogens, Infectious diseases, Wild boar, Public health, Serology, Hygiene, Hunting

\section{INTRODUCTION}

Wild boars (Sus scrofa), also known as wild pigs or feral pigs in the USA, have strongly expanded their range in northern Europe during the last decade (von Essen 2019).

Supplementary Information: The online version of this article (https://doi.org/10. 1007/s10393-020-01509-5) contains supplementary material, which is available to authorized users.

Published online: December 16, 2020

Correspondence to: Maria Fredriksson-Ahomaa, e-mail: maria.fredriksson-ahomaa@helsinki.fi
They are also very intensively hunted in Europe (Vajas et al. 2020) and the most important hunting species in the world (Massei et al. 2015). In Finland, the wild boar population has increased drastically during the past years with large regional differences in the population densities. Highest wild boar numbers have been reported in southeastern Finland near the Russian border, where approximately 25\% of wild boars live (Natural Resources Institute Finland). A warming climate with milder winters and scarce snow is enabling the species to spread northwards and become more numerous (Markov et al. 2019). They will also continue to expand due to their high adaptability and high 
reproductive potential. Wild boars cause extensive agricultural damages and traffic accidents, but they are also a risk to human and animal health (Fredriksson-Ahomaa 2019).

Wild boars can be infected with several pathogens that are transmittable to other wildlife, domestic animals and humans (Fredriksson-Ahomaa 2019). Wild boars carry Brucella suis, Salmonella, Yersinia enterocolitica and Y. pseudotuberculosis, Toxoplasma gondii, Trichinella and hepatitis E virus (HEV) in Europe (Anheyer-Behmenburg et al. 2017; Kantala and Maunula. 2018; Bonardi et al. 2019; Laforet et al. 2019). Furthermore, stx-positive Escherichia coli (STEC) and Listeria monocytogenes have been detected in wild boar samples (Dias et al. 2019). These pathogens are all transmittable to humans through contaminated food. Wild boar meat is also recognized as an important source of Trichinella and T. gondii. A possible link of foodborne zoonoses between wild boars, domestic animals and humans has raised increasing interest among researchers (Bonardi et al. 2019). Wild boars may also act as reservoirs for many important livestock infectious diseases such as African swine fever (ASF), classical swine fever (CSF) and Aujeszky's disease (AD) (Meier et al. 2015; Postel et al. 2018; Gallardo et al. 2019).

The purpose of this work was to study the prevalence of antibodies to Salmonella, pathogenic Yersinia spp., T. gondii, Trichinella and HEV, which are all important meatborne pathogens associated with domestic and wild pig populations. Furthermore, Salmonella, ail-positive Yersinia spp., Campylobacter spp., STEC and L. monocytogenes were studied by PCR and culturing from the visceral organs. We additionally report the monitoring results for brucellosis, AFS, CSF and AD.

\section{MethodS}

\section{Samples}

Finnish hunters collected samples (blood, spleen and kidneys) from 366 wild boars, which were intended for monitoring of brucellosis, ASF, CSF and AD, and sent them to the Finnish Food Safety Authority (the Finnish Food Authority from 1.1.2019 onward) between January and December 2016. Spleen and kidneys from each animal were shipped together in a plastic bag. We studied the prevalence of antibodies to the most important pork-borne zoonotic pathogens (Salmonella, Yersinia, T. gondii, Trichinella and
HEV) from the serum samples. Furthermore, the presence of Salmonella, Y. enterocolitica, Y. pseudotuberculosis, Campylobacter spp., STEC and L. monocytogenes was studied from the visceral organ samples (spleen and kidneys) by PCR. Additionally, antibodies to Brucella, CSF virus (CSFV) and $A D$ virus (ADV) were studied in wild boars. The presence of CSFV, ASF virus (ASFV) and ADV was studied using PCR.

\section{Serology}

We studied antibodies to Salmonella, Yersinia, T. gondii and Trichinella in serum samples using commercial enzymelinked immunosorbent assay (ELISA) Pigtype ${ }^{\circledR}$ test kits (Qiagen, Leipzig, Germany). According to the manufacturer, the sensitivity and specificity of the tests were $98.5 \%$ and $99.8 \%$ for Salmonella, $98.9 \%$ and $92.7 \%$ for T. gondii and $98.9 \%$ and $95.4 \%$ for Trichinella. For the Yersinia test, the sensitivity and specificity were both near $100 \%$ according to the manufacturer. Samples with an S/P ratio $<0.3$ were considered negative. The PrioCHEC$\mathrm{K} \circledast \mathrm{HEV}$ ab porcine ELISA test $(91.0 \%$ sensitivity and 94.0\% specificity) (Prionics AG, Zurich, Switzerland) was used for detecting HEV antibodies. The cutoff value was calculated according to the manufacturer's instructions. Antibodies to Brucella were studied in serum samples using two tests: Rose Bengal (RB) rapid slide agglutination test (Pourquier ${ }^{\circledR}$ Rose Bengale Ag, IDEXX, France) and multispecies indirect ELISA test (sensitivity and specificity near 100\%) (ID Screen ${ }^{\circledR}$ Brucellosis, IDVet, France). All samples were studied by RB and RB-positive samples also by ELISA. We studied the presence of antibodies to the CSFV using PrioCHECK ${ }^{\circledR}$ CSFV Antibody 2.0 ELISA assay (95.4\% sensitivity and $100 \%$ specificity) (Prionics AG) and to the ADV using SVANOVIR ${ }^{\circledR}$ PRV gB-Ab ELISA assay (99.6\% sensitivity and $99.3 \%$ specificity) (Svanova, Uppsala, Sweden).

\section{PCR Screening}

We studied the presence of Campylobacter, Salmonella, ailpositive Yersinia spp., STEC and L. monocytogenes using real-time PCR based on SYBRGreen according to Sauvala et al. (2019). DNA was extracted from the organs after overnight enrichment [10 g samples in $90 \mathrm{ml}$ of buffered peptone water (BPW, Labema, Helsinki, Finland)] at $37{ }^{\circ} \mathrm{C}$ for 10-20 h using ZR Fecal DNA MiniPred ${ }^{\mathrm{TM}}$ (Nordic BioSite Oy, Helsinki, Finland). We studied the presence of 
ASFV, CSFV and ADV using PCR according to FernándezPinero et al. (2013), Hoffmann et al. (2006) and Wernike et al. (2014), respectively.

\section{Isolation and Identification}

PCR-positive Campylobacter, Salmonella, Yersinia and Listeria samples were isolated from the overnight enrichments using selective agar plates (Labema): CCDC and CHROMagar ${ }^{\mathrm{TM}}$ Campylobacter for Campylobacter, XLD and CHROMagar ${ }^{\mathrm{TM}}$ SalmonellaPLUS for Salmonella, CIN and CHROMagar ${ }^{\mathrm{TM}}$ Yersinia enterocolitica for Yersinia and CHROMagar ${ }^{\mathrm{TM}}$ Listeria for Listeria. Up to four typical colonies on selective agar plates were cultured on blood agar. All plates for Salmonella, Campylobacter and Listeria isolation were incubated at $37{ }^{\circ} \mathrm{C}$ and plates for Yersinia at $30{ }^{\circ} \mathrm{C}$ for $24-48$ h. Salmonella and Yersinia colonies were identified with API 20E and Listeria colonies with API Listeria (BioMerieux, France). We studied the pathogenicity of the Yersinia isolates with PCR detecting the chromosomal ail gene and the plasmid-borne virF gene. Serotyping was performed with commercial antisera (Denka Seikan, Japan). Brucella was isolated using Farrell's selective agar plates (Oxoid, Basingstoke, UK) and Columbia blood agar plates containing bovine serum (Oxoid). The plates were incubated at $37{ }^{\circ} \mathrm{C}$ in an aerobic and microaerophilic atmosphere and observed for $10 \mathrm{~d}$. Presumptive identification was based on Stamp staining and on the oxidase, catalase and urease tests. Further identification was performed with three PCR methods: (1) Genus identification was performed according to Bounaadja et al. (2009), and (2) species and (3) biovar were identified according to López-Goñi et al. (2011). Brucella isolation was performed in a biosafety level three (BSL-3) laboratory.

\section{Multi-locus Sequence Typing MLST}

We purified the DNA of $Y$. pseudotuberculosis and $L$. monocytogenes isolates with PureLink Genomic DNA Mini Kit (Invitrogen, Carlsbad, USA). Whole-genome sequence was performed on the Illumina platform using NovaSeq6000 (Center for Genomics and Transcriptomics, Tuebingen, Germany) with paired end reads. Isolates were sequenced with $100 \times$ coverage and $2 \times 100$ bp read length. Genome assembly was conducted using Patric webbased service (https://www.patricbrc.org/app/Assembly). The assembled contigs were analyzed with the web-based service of the Center for Genomic Epidemiology (https://
cge.cbs.dtu.dk/services/MLST/): Sequence types (STs) of $Y$. pseudotuberculosis were determined with the MLST scheme for Y. pseudotuberculosis, and STs of L. monocytogenes were determined with the MLST scheme for $L$. monocytogenes.

\section{Statistical Analyses}

Statistical analyses were carried out with the analytical software package SPSS ${ }^{\circledR}$ Statistics Version 25. Multiple logistic regression analysis was used to assess the association between potential risk factors (age and gender) and the presence of antibodies to foodborne pathogens. $P$-values below 0.05 were considered statistically significant.

\section{Results}

A total of 181 wild boars, hunted in 12 out of 19 regions in Finland, were tested for antibodies to foodborne pathogens. Most (78\%) of the 181 wild boars had been hunted in southeastern Finland, in region 7 (South Karelia) and region 16 (Kymenlaakso) (Figure S1). Both regions have the highest wild boar densities and a land border with Russia.

Table 1. Geographical Locations (Regions) of the 181 Hunted Wild Boars.

\begin{tabular}{|c|c|c|c|c|c|c|c|}
\hline \multirow{3}{*}{$\begin{array}{l}\text { Region } \\
2\end{array}$} & \multirow{2}{*}{\multicolumn{2}{|c|}{$\begin{array}{l}\text { Number of } \\
\text { wild boars }\end{array}$}} & \multicolumn{3}{|c|}{ Gender } & \multicolumn{2}{|l|}{ Age } \\
\hline & & & \multirow{2}{*}{$\frac{\text { Male }}{2}$} & \multirow{2}{*}{$\begin{array}{l}\text { Female } \\
1\end{array}$} & \multirow{2}{*}{$\frac{\mathrm{NR}^{\mathrm{b}}}{1}$} & \multirow{2}{*}{$\frac{\text { Adult }}{1}$} & \multirow{2}{*}{$\frac{\text { Young }}{3}$} \\
\hline & 4 & $(5)^{\mathrm{a}}$ & & & & & \\
\hline 3 & 1 & (2) & 1 & 0 & 0 & 1 & 0 \\
\hline 4 & 9 & (15) & 3 & 6 & 0 & 6 & 3 \\
\hline 5 & 2 & (8) & 1 & 1 & 0 & 2 & 0 \\
\hline 6 & 1 & (6) & 1 & 0 & 0 & 1 & 0 \\
\hline 7 & 83 & $(126)$ & 41 & 40 & 2 & 35 & 48 \\
\hline 8 & 3 & (18) & 1 & 2 & 0 & 1 & 2 \\
\hline 12 & 3 & (6) & 1 & 2 & 0 & 1 & 2 \\
\hline 13 & 0 & (1) & & & & & \\
\hline 14 & 2 & (14) & 2 & 0 & 0 & 1 & 1 \\
\hline 15 & 1 & (2) & 0 & 1 & 0 & 1 & 0 \\
\hline 16 & 58 & $(125)$ & 31 & 26 & 1 & 31 & 27 \\
\hline 17 & 14 & (35) & 9 & 5 & 0 & 7 & 7 \\
\hline 18 & 0 & (3) & & & & & \\
\hline All & 181 & $(366)$ & 93 & 84 & 4 & 88 & 93 \\
\hline
\end{tabular}

${ }^{\mathrm{a}}$ Number of wild boars obtained for the monitoring.

${ }^{\mathrm{b}}$ Not reported. 
We obtained gender information for 177 out of 181 wild boars and age information for all 181 wild boars (Table 1). The animals were reported as young (below 1 year of age) or adults (over 1 year) based on tooth eruption ( $>12$ months of age: 2 . molar has erupted). Adult males $(n=49)$ were slightly more common than young males $(n=44)$, and young females $(n=45)$ were slightly more common than adult females $(n=39)$.

The number of wild boars studied per month varied between 0 and 50 animals (Figure S2). No samples were obtained from April to May, which is the farrowing time when fewer wild boars are hunted. The highest number $(n=50)$ was obtained in November.

Antibodies to Salmonella and Yersinia were found in $38 \%(69 / 181)$ and $56 \%(102 / 181)$ of the wild boars, respectively (Table 2 ). HEV antibodies were found in $18 \%$ (32/181) wild boars. T. gondii antibodies were detected in 9\% (17/181) and Trichinella antibodies in 1\% (2/181) of the wild boars. Antibodies to pathogens, especially Salmonella, Yersinia and HEV, were frequently found in wild boars hunted in regions 7 and 16 in southeastern Finland.

The seroprevalence of Salmonella, Yersinia, T. gondii, Trichinella and HEV infections did not differ significantly $(P>0.05)$ between male and female wild boars (Table 3$)$. However, males were 2.3 times more likely to carry antibodies to any of these pathogens than females $(P=0.017)$.
Age significantly influenced the presence of Yersinia $(P=0.021)$ and T. gondii $(P=0.011)$ antibodies; adult wild boars were 2.0 times more likely to carry Yersinia antibodies and 5.3 times more likely to carry $T$. gondii antibodies than young wild boars. Trichinella antibodies were detected in two wild boars: Both were adult females.

L. monocytogenes $(48 \%, 63 / 130)$ and STEC (33\%, 43/ 130) determinants were the most common findings in wild boars with PCR (Table 4). Yersinia carrying the ail gene was detected in $17 \%(22 / 130)$ of the animals, while Salmonella and Campylobacter determinants were found in 5\% (6/130) of the individuals by PCR.

L. monocytogenes and Y. pseudotuberculosis could be isolated from the visceral organs (spleen and kidneys) (Table 5). Fifty-two L. monocytogenes isolates originated from $40(30 \%)$ wild boars. Nearly all L. monocytogenes isolates belonged to serotype $2 \mathrm{a}$, but two isolates from two wild boars were identified as serotype $4 \mathrm{~b}$. Several STs were obtained from L. monocytogenes isolates. Y. pseudotuberculosis was isolated from two wild boars, both of which were young females from region 7 (South Karelia). The isolates belonged to serotype O:1 and ST42.

Antibodies to Brucella were detected in 9\% (8/87) of wild boars. Visceral organs were available from 5 out of 8 seropositive animals of which $B$. suis biovar 2 was isolated from 4 wild boars. All positive animals were hunted in

Table 2. Seroprevalence of Foodborne Zoonoses in Wild Boars Hunted in 12 Regions in Finland.

\begin{tabular}{|c|c|c|c|c|c|c|}
\hline \multirow[t]{2}{*}{ Region } & \multirow[t]{2}{*}{ Number of wild boars } & \multicolumn{5}{|c|}{ Number of wild boars with antibodies to } \\
\hline & & Salmonella & Yersinia & Toxoplasma & Trichinella & HEV \\
\hline 2 & 4 & 1 & 3 & 0 & 0 & 0 \\
\hline 3 & 1 & 0 & 1 & 1 & 0 & 0 \\
\hline 4 & 9 & 3 & 7 & 2 & 0 & 3 \\
\hline 5 & 2 & 0 & 2 & 0 & 0 & 0 \\
\hline 6 & 1 & 1 & 0 & 0 & 0 & 0 \\
\hline 7 & 83 & 33 & 41 & 4 & 1 & 14 \\
\hline 8 & 3 & 0 & 0 & 0 & 0 & 0 \\
\hline 12 & 3 & 1 & 3 & 0 & 0 & 1 \\
\hline 14 & 2 & 1 & 1 & 1 & 0 & 0 \\
\hline 15 & 1 & 0 & 1 & 0 & 0 & 1 \\
\hline 16 & 58 & 25 & 34 & 6 & 1 & 10 \\
\hline 17 & 14 & 4 & 9 & 3 & 0 & 3 \\
\hline Total & 181 & $69(38 \%)$ & $102(56 \%)$ & $17(9 \%)$ & $2(1 \%)$ & $32(18 \%)$ \\
\hline \multicolumn{2}{|c|}{$95 \%$ confidence intervals } & $31 \%-46 \%$ & $49 \%-64 \%$ & $6 \%-15 \%$ & $1 \%-4 \%$ & $12 \%-24 \%$ \\
\hline
\end{tabular}


Table 3. Prevalence of Antibodies to Foodborne Zoonotic Pathogens in Young and Adult/Female and Male Wild Boars.

\begin{tabular}{|c|c|c|c|c|c|}
\hline \multirow[t]{2}{*}{ Antibodies to } & \multirow[t]{2}{*}{ Variables } & & \multirow{2}{*}{$\begin{array}{l}\text { Seropositivity } \\
\mathrm{N}(\%)\end{array}$} & \multirow[t]{2}{*}{ Odds ratio $(\mathrm{CI} 95 \%)^{\mathrm{a}}$} & \multirow[t]{2}{*}{$P$-value ${ }^{\mathrm{b}}$} \\
\hline & & & & & \\
\hline \multirow[t]{4}{*}{ Salmonella } & Age & Young & $34(39 \%)$ & & $>0.05$ \\
\hline & & Adult & $34(39 \%)$ & & \\
\hline & Gender & Female & $28(33 \%)$ & & $>0.05$ \\
\hline & & Male & $40(43 \%)$ & & \\
\hline \multirow[t]{4}{*}{ Yersinia } & Age & Young & $43(48 \%)$ & $2.04(1.11-3.75)$ & 0.021 \\
\hline & & Adult & $58(66 \%)$ & & \\
\hline & Gender & Female & $45(54 \%)$ & & $>0.05$ \\
\hline & & Male & $65(60 \%)$ & & \\
\hline \multirow[t]{4}{*}{ Toxoplasma } & Age & Young & $3(3 \%)$ & $5.30(1.46-19.21)$ & 0.011 \\
\hline & & Adult & $14(16 \%)$ & & \\
\hline & Gender & Female & $6(7 \%)$ & & $>0.05$ \\
\hline & & Male & $11(12 \%)$ & & \\
\hline \multirow[t]{4}{*}{ Trichinella } & Age & Young & 0 & & $>0.05$ \\
\hline & & Adult & $2(2 \%)$ & & \\
\hline & Gender & Female & $2(2 \%)$ & & $>0.05$ \\
\hline & & Male & 0 & & \\
\hline \multirow[t]{4}{*}{$\mathrm{HEV}$} & Age & Young & $15(16 \%)$ & & $>0.05$ \\
\hline & & Adult & $17(19 \%)$ & & \\
\hline & Gender & Female & $15(18 \%)$ & & $>0.05$ \\
\hline & & Male & $17(18 \%)$ & & \\
\hline \multirow[t]{4}{*}{ Any pathogen } & Age & Young & $63(71 \%)$ & & $>0.05$ \\
\hline & & Adult & $66(75 \%)$ & & \\
\hline & Gender & Female & $54(64 \%)$ & $2.29(1.16-4.54)$ & 0.017 \\
\hline & & Male & $75(81 \%)$ & & \\
\hline
\end{tabular}

${ }^{\text {a }}$ Multiple logistic regression analysis.

${ }^{\mathrm{b}} P$-value $<0.05$ is considered significant.

South Karelia (region 7), which is located in southeastern Finland and has a long land border with Russia. No ASFV was detected in 366 wild boars by PCR. Furthermore, no CSFV was detected in 230 and 366 wild boars and ADV in 234 and 362 wild boars by serology and PCR, respectively.

\section{Discussion}

A high seroprevalence (38\%) of Salmonella infection was detected in wild boars hunted in Finland in 2016. Salmonella prevalence reached $40 \%$ and $43 \%$, in southeastern regions 7 and 16 with Russian land border, respectively. Only a few serological studies have recently been conducted on Salmonella in wild boars (Fredriksson-Ahomaa 2019). In Spain, a seroprevalence of $11 \%$ was reported in wild boars quite recently (Cano-Manuel et al. 2014). Interest- ingly, Salmonella was detected in $27 \%$ of wild boars in Sweden using PCR, mostly in the tonsils (Sannö et al. 2018). There are no data available about Salmonella from wild boars in Finland. Wild boars frequently carry Salmonella in their tonsils, but Salmonella also colonizes the lymph nodes and is excreted in the feces (Sannö et al. 2018; Bonardi et al. 2019; Gil Molino et al. 2019). In Belgium, Salmonella was recently detected in one third of wild boar meat samples (Peruzy et al. 2019). Salmonella and other bacteria can easily be transmitted from the tonsils and feces to the carcass and visceral organs during evisceration, especially due to poor hunting hygiene out in the field or due to gut hit (Sauvala et al. 2019). In our study, Salmonella determinant $(t t r)$ was detected in $5 \%$ of the visceral organs using PCR, but no Salmonella was found by culturing indicating a low contamination level of the organs. The organs have also been stored at $-20{ }^{\circ} \mathrm{C}$ for a pro- 
Table 4. Detection Rate of Foodborne Pathogens in Wild Boars by PCR.

\begin{tabular}{|c|c|c|c|c|c|c|}
\hline \multirow[t]{2}{*}{ Region } & \multirow[t]{2}{*}{ Number of wild boars } & \multicolumn{5}{|c|}{ Wild boar positive for genes } \\
\hline & & $r r n$ & $t t r$ & ail & $m p l$ & $s t x$ \\
\hline 2 & 3 & 0 & 0 & 0 & 3 & 3 \\
\hline 3 & 1 & 0 & 0 & 0 & 0 & 0 \\
\hline 4 & 6 & 0 & 1 & 1 & 3 & 3 \\
\hline 5 & 1 & 0 & 0 & 0 & 0 & 0 \\
\hline 7 & 66 & 6 & 2 & 12 & 26 & 23 \\
\hline 12 & 3 & 0 & 0 & 0 & 2 & 2 \\
\hline 14 & 2 & 0 & 0 & 0 & 1 & 0 \\
\hline 15 & 1 & 0 & 0 & 0 & 0 & 0 \\
\hline 16 & 36 & 0 & 2 & 7 & 21 & 9 \\
\hline 17 & 11 & 0 & 1 & 2 & 7 & 3 \\
\hline Total & 130 & $6(5 \%)$ & $6(5 \%)$ & $22(17 \%)$ & $63(48 \%)$ & $43(33 \%)$ \\
\hline
\end{tabular}

$r r n=$ Campylobacter,$t t r=$ Salmonella, ail $=$ Yersinia,$m p l=L$. monocytogenes, st $x=$ STEC

Table 5. Listeria monocytogenes and Yersinia pseudotuberculosis Isolates from Wild Boars.

\begin{tabular}{|c|c|c|c|c|c|c|c|}
\hline \multirow[t]{2}{*}{ Region } & \multicolumn{4}{|c|}{ Listeria monocytogenes } & \multicolumn{3}{|c|}{ Yersinia pseudotuberculosis } \\
\hline & \multicolumn{2}{|c|}{ Isolates (Animals) } & Serotypes & Sequence types (STs) & Isolates (Animals) & \multirow[t]{2}{*}{ Serotype } & \multirow{2}{*}{$\begin{array}{l}\text { Sequence } \\
\text { type (ST) }\end{array}$} \\
\hline 4 & 2 & $(1)$ & $2 \mathrm{a}$ & & 0 & & \\
\hline 7 & 29 & $(21)$ & $2 a, 4 b$ & $1, \mathbf{1 8}^{\mathrm{a}}, 20,21,91,399,451$ & (2) & O:1 & 42 \\
\hline 12 & 1 & $(1)$ & $2 \mathrm{a}$ & & 0 & & \\
\hline 14 & 3 & (3) & $2 \mathrm{a}$ & 451 & 0 & & \\
\hline 16 & 12 & $(10)$ & $2 \mathrm{a}$ & $8,37,451,573$ & 0 & & \\
\hline 17 & 5 & $(4)$ & $2 \mathrm{a}$ & 7 & 0 & & \\
\hline Total & 52 & $(40)$ & & & (2) & & \\
\hline
\end{tabular}

${ }^{a}$ Bold STs have been found on moose and deer carcasses in Finland (Sauvala et al. 2019).

longed time before culturing, which could have influenced the viability of the cells. Unfortunately, we did not test feces or tonsil samples, which are the matrices of choice to estimate Salmonella prevalence in wild boars (Sannö et al. 2014). However, slaughter waste should not be left out in the forest because it may pose the risk of Salmonella spreading to other wild and domestic animals. Finland, Sweden and Norway have very low Salmonella isolation rates in domestic pigs $(<1 \%)$ compared to other European countries (EFSA and ECDC 2018). Biosecurity in pig farms is crucial for reducing the risk of introducing Salmonella from wildlife into the pork production chain.

The seroprevalence of Yersinia infection in wild boars was high $(56 \%)$ in our study. A high seroprevalence has also been reported in the Czech Republic (66\%), Latvia (69\%) and Spain (52\%) showing that wild boars are frequently infected with Yersinia (Arrausi-Subiza et al. 2016; Lorencova et al. 2016; Grantina-Ievina et al. 2018). In our study, antibodies to Yersinia were significantly more frequently detected in adults than in young wild boars, which is in accordance with a study from Spain (Arrausi-Subiza et al. 2016). Y. enterocolitica and Y. pseudotuberculosis have been detected particularly in the tonsils, constituting a contamination risk for carcasses during slaughter (Wacheck et al. 2010; Sannö et al. 2014, 2018; Reinhardt et al. 2018). In our study, $17 \%$ of the visceral organs were contaminated with ail-positive Yersinia; however, only $Y$. pseudotuberculosis serotype O:1 was isolated from the 
samples. Serotype O:1 belonging to the sequence type ST42 is a common type reported in wild boars (FredrikssonAhomaa et al. 2011; Reinhardt et al. 2018). This type has also been identified in humans in Europe (http://enteroba se.warwick.ac.uk/species/index/yersinia). Seroprevalence of yersiniosis is also high in fattening pigs in Europe including Finland (Felin et al. 2019). However, the etiology seems to differ between domestic pigs and wild boars. The infection agent in domestic pigs is typically $Y$. enterocolitica of bioserotype 4/O:3, and $Y$. pseudotuberculosis is a rare finding. Wild boars seem to be infected with Y. pseudotuberculosis and $Y$. enterocolitica belonging to different genotypes than domestic pigs (Fredriksson-Ahomaa et al. 2011). Domestic pigs are usually infected during the fattening period, and their seroprevalence decreases with age, being low in sows. In wild boars, seroprevalence was significantly higher in adult than in young animals indicating infection or reinfection at an older age.

HEV is the most important meat-borne zoonotic virus. Wild boars are an important reservoir of HEV in Europe (Kantala and Maunula 2018; Fredriksson-Ahomaa 2019). Antibodies to HEV were detected in $18 \%$ of wild boars in our study. A seroprevalence of over 50\% has quite recently been reported in Germany, Italy, Lithuania and Spain (Mazzei et al. 2015; Kukielka et al. 2016; Spancerniene et al. 2016; Anheyer-Behmenburg et al. 2017). Foodborne HEV transmission has been associated with the liver, meat and sausages of wild boar (Fredriksson-Ahomaa 2019). A high HEV load ( $>10^{5}$ genomic copies/g) has recently been reported in wild boar liver in Italy (Di Pasquale et al. 2019). Genetically highly related HEV strains have been reported among humans, domestic pigs and wild boars in European countries indicating interspecies transmission of HEV (Jemeršic et al. 2019; Wang et al. 2019). A high prevalence of hepatitis E among wild boars and the similarity of HEV strains between wild boars and humans indicate that zoonotic transmission from wild boars may be more common than previously expected (Wang et al. 2019).

We observed a $9 \%$ seroprevalence of $T$. gondii infection in wild boar. A clearly higher seroprevalence (50\%) was reported in Sweden (Wallander et al. 2015). One reason for this may be the higher wild boar density and more frequent contact with cat feces in Sweden compared to Finland. $T$. gondii antibodies were detected in 33\% of farmed wild boars in Finland (Jokelainen et al. 2012) but only in 1\% of fattening pigs bred under a controlled housing system (Felin et al. 2019). A T. gondii seroprevalence of $28 \%$ in fenced wild boars in Denmark was recently reported (La- foret et al. 2019). A high seroprevalence of ca. $40 \%$ was reported in wild boars in the Czech Republic, Italy and Slovakia (Racka et al. 2015; Reiterová et al. 2016; Gazzonis et al. 2018). In our study, T. gondii antibodies were significantly more frequently detected in adults than in young wild boars, which is in accordance with earlier studies (Fredriksson-Ahomaa 2019). A higher prevalence in older than in young animals is most probably due to their greater exposure to the parasite. Recently, T. gondii was frequently reported in wild boar tissue samples (brain: $31 \%$, heart: $28 \%$ and masseter muscle: $24 \%$ ) in southern Italy (Santoro et al. 2019). Consumption of undercooked wild boar meat is expected to be a risk for contracting human toxoplasmosis. However, since $T$. gondii is sensitive to freezing (Jones and Dubey et al. 2012), only frozen wild boar meat should be used for consumption, if not thoroughly heat treated. Jones and Dubey (2012) recommend cooking wild boar meet to $71{ }^{\circ} \mathrm{C}$ or higher with a 3 -min rest to avoid toxoplasmosis.

Antibodies to Trichinella were detected in only $1 \%$ of the wild boars in our study. An exceptionally high seroprevalence of $42 \%$ has been reported in Estonia (Kärssin et al. 2016). Before the AFS epidemic in 2014, wild boar density was very high in Estonia, allowing close interaction between wild boars and other wild animals. Wild boar meat has recently been responsible for several human Trichinella outbreaks in Europe (Faber et al. 2015; Fichi et al. 2015; Van De et al. 2015; Messiaen et al. 2016; Heaton et al. 2018). Wild boar carcasses should be appropriately tested to prevent human exposure to Trichinella (Noeckler et al. 2019). Trichinella testing is required for all wild boars entering the community trade in Europe according to the legislation (Regulations (EC) No 853/2004). Freezing only is not recommended because $T$. native and $T$. britovi are relatively freeze resistant (Noeckler et al. 2019). These two species are the most common ones identified in wildlife in Finland (Oksanen et al. 2018). Cooking at core temperature between $63{ }^{\circ} \mathrm{C}$ and $71{ }^{\circ} \mathrm{C}$ for $3 \mathrm{~min}$ inactivates Trichinella larvae in meat (Noeckler et al. 2019).

We also studied the presence of Campylobacter, STEC and L. monocytogenes determinants in the visceral organs of wild boars using PCR and culturing. We used PCR to screen positive samples before culturing because it is a more rapid, sensitive and specific method compared to culturing. However, PCR detects also dead cells, which can cause false positive results. The PCR prevalence of Campylobacter was 5\%, and no isolates were found by culturing. Furthermore, Campylobacter will usually not 
survive on a dry carcass surface and is heat sensitive (Nesbakken et al. 2008, Silva et al. 2011). This indicates that wild boar meat is a relatively low risk of Campylobacter infection. A high PCR prevalence of STEC and L. monocytogenes determinants was detected in the visceral organs. Bacterial contamination of game carcasses and organs occurs easily during evisceration in the field (Sauvala et al. 2019). STEC was studied only with a PCR method targeting the $s t x 1$ and $s t x 2$ genes and not by culturing; further investigations are thus needed to confirm the public health relevance. The isolation rate of $L$. monocytogenes was surprisingly high. Serotypes $2 \mathrm{a}$ and $4 \mathrm{~b}$ identified in wild boars have also been found on moose and deer carcasses in Finland (Sauvala et al. 2019). Several sequence types were obtained, most of which have been identified in humans in Europe (https://bigsdb.pasteur.fr/listeria/). Sequence types ST7, ST8, ST18, ST37 and ST451 of serotype 2a and ST1 of serotype $4 \mathrm{~b}$ found in wild boars in Finland have also been found in humans with listeriosis (Finnish Institute for Health and Welfare). The link between wild boar/wildlife and human infections needs further studies. However, $L$. monocytogenes is tolerant to cold. It has an ability to grow at temperatures around $0{ }^{\circ} \mathrm{C}$, and therefore, storing wild boar meat in a refrigerator may present a public health risk (Hingston et al. 2017).

Antibodies to Brucella were found in $9 \%$ of the wild boars in Finland in 2016. Antibodies to Brucella have been detected in wild boars in several European countries: A very high seroprevalence was reported in Spain, while no antibodies to Brucella were reported in Sweden (FredrikssonAhomaa 2019). Several European countries have achieved Brucella-free status in livestock. This includes Finland, where Brucella has never been reported in domestic pigs. $B$. suis biovar 2, which was found in wild boars in Finland for the first time in 2015, was also found in 2016. B. suis biovar 2 is the most common type responsible for brucellosis in wild boars and hares in Europe (De Massis et al. 2019; Muñoz et al. 2019). Brucellosis may cause major economic losses in the pig industry, especially in pigs with outdoor access. Brucellosis due to B. suis biovar 2 has been reported in hunters, most probably due to direct contact with organs and tissues of infected wild boars (Mailles et al. 2017).

Several animal diseases, such as ASF, CSF and AD, are monitored in domestic pigs and wild boars in Finland. Wild boars hunted in Finland in 2016 were negative for these contagious diseases. However, wild boars are important reservoir of ASFV, CSFV and ADV in several European countries and may also transmit these pathogens to domestic pigs causing tremendous economic losses in the pig production chain (Meier et al. 2015; Postel et al. 2018; Gallardo et al. 2019). ASF has so far never been detected Finnish domestic pigs or wild boars, and CFS has not been detected since 2017. ASF has been detected in regions close to Finland, and the risk of its spread to Finland has increased (Finnish Food Authority). Wild boars have been monitored for ASF since 2010, and all wild boars found dead should be reported to local municipal veterinarians soon as possible. AD has never been diagnosed in Finnish domestic pigs. However, $\mathrm{AD}$ was reported for the first time in a wild boar in September 2019. It was hunted in the North Karelia (region 4), close to the Russian border. Effective biosecurity measures at the farm level and a low wild boar density are very important in preventing the spread of contagious diseases to pig farms and resulting in huge economic losses in the pig production chain.

\section{CONCLUSION}

Wild boars are important reservoirs for foodborne zoonoses. Our study demonstrated a high seroprevalence of Salmonella and Yersinia infections, but we also detected antibodies to Brucella, T. gondii, Trichinella and HEV in hunted wild boars. Wild boars may transmit these foodborne pathogens to other animals and hamper the control of these pathogens in the food-producing chain. L. monocytogenes was frequently detected in the visceral organs stressing the importance of proper hygiene when handling wild boar organs. Monitoring of infectious diseases in wild boars may help to implement locally customized public and animal health control strategies to avoid financial losses in food production chain.

\section{ACKNOWLEDGEMENTS}

We thank Maria Stark and Ana López Martínez for excellent assistance in the microbiological laboratory at the Department of Food Hygiene and Environmental Health. The staff at the Virological and Bacteriological Units of Finnish Food Authority are also acknowledged for their contribution. Financial support of part of this work was from Finnish Foundation of Veterinary Research. 


\section{FUNDING}

Open access funding provided by University of Helsinki including Helsinki University Central Hospital.

\section{Compliance with Ethical Standards}

CONFLICT OF INTEREST The authors declare that they have no conflicts of interest.

\section{Open Access}

This article is licensed under a Creative Commons Attribution 4.0 International License, which permits use, sharing, adaptation, distribution and reproduction in any medium or format, as long as you give appropriate credit to the original author(s) and the source, provide a link to the Creative Commons licence, and indicate if changes were made. The images or other third party material in this article are included in the article's Creative Commons licence, unless indicated otherwise in a credit line to the material. If material is not included in the article's Creative Commons licence and your intended use is not permitted by statutory regulation or exceeds the permitted use, you will need to obtain permission directly from the copyright holder. To view a copy of this licence, visit http://creativec ommons.org/licenses/by/4.0/.

\section{REFERENCES}

Anheyer-Behmenburg HE, Szabo K, Schotte U, Binder A, Klein G, Johne R (2017) Hepatitis E virus in wild boars and spillover infection in red and roe deer, Germany, 2013-2015. Emerging Infectious Diseases 23:130-133

Arrausi-Subiza M, Gerrikagoitia X, Alvarez V, Ibabe JC, Barral M (2016) Prevalence of Yersinia enterocolitica and Yersinia pseudotuberculosis in wild boars in the Basque Country, northern Spain. Acta Veterinaria Scandinavica 58:4

Bonardi S, Bolzoni L, Zanoni RG, Morganti M, Corradi M, Gilioli S, et al. (2019) Limited exchange of Salmonella among domestic pigs and wild boars in Italy. EcoHealth 16:420-428

Bounaadja L, Albert D, Chénais B, Hénault S, Zygmunt MS, Poliak S, et al. (2009) Real-time PCR for identification of Brucella spp.: A comparative study of IS711, bcsp31 and per target genes. Veterinary Microbiology 137:156-164

Cano-Manuel FJ, López-Olvera J, Fandos P, Soriguer RC, Pérez JM, Granados JE (2014) Long-term monitoring of 10 selected pathogens in wild boar (Sus scrofa) in Sierra Nevada National Park, southern Spain. Veterinary Microbiology 174:148-154
De Massis F, Zilli K, Donato GD, Nuvoloni R, Pelini S, Sacchini L, et al. (2019) Distribution of Brucella field strains isolated from livestock, wildlife populations, and humans in Italy from 2007 to 2015. PLoS ONE 14:e0213689

Di Pasquale S, De Santis P, La Rosa G, Di Domenico K, Iaconelli M, Micarelli G, et al. (2019) Quantification and genetic diversity of hepatitis E virus in wild boar (Sus scrofa) hunted for domestic consumption in Central Italy. Food Microbiology 82:194-201

Dias D, Caetano T, Torres RT, Fonseca C, Mendo S (2019) Shiga toxin-producing Escherichia coli in wild ungulates. Science of the Total Environment 651:203-209

EFSA and ECDC (2018) The European Union summary report on trends and sources of zoonoses, zoonotic agents and food-borne outbreaks in 2017. EFSA Journal 16:e5500

Faber M, Schink S, Mayer-Scholl A, Ziesch C, Schönfelder R, Wichmann-Schauer H, et al. (2015) Outbreak of trichinellosis due to wild boar meat and evaluation of the effectiveness of post exposure prophylaxis, Germany, 2013. Clinical Infectious Diseases 60:e98-104

Felin E, Hälli O, Heinonen M, Jukola E, Fredriksson-Ahomaa M (2019) Assessment of the feasibility of serological monitoring and on-farm information about health status for the future meat inspection of fattening pigs. Preventive Veterinary Medicine $162: 76-82$

Fichi G, Stefanelli S, Pagani A, Luchi S, De Gennaro M, GómezMorales MA, et al. (2015) Trichinellosis outbreak caused by meat from a wild boar hunted in an Italian region considered to be at negligible risk for Trichinella. Zoonoses and Public Health 62:285-291

Fredriksson-Ahomaa M (2019) Wild boar: a reservoir of foodborne zoonoses. Foodborne Pathogens and Disease 16:153-165

Fredriksson-Ahomaa M, Wacheck S, Bonke R, Stephan R (2011) Different enteropathogenic Yersinia strains found in wild boars and domestic pigs. Foodborne Pathogens and Disease 8:733-737

Gallardo C, Fernández-Pinero J, Arias M (2019) African swine fever (ASF) diagnosis, an essential tool in the epidemiological investigation. Virus Research 271:197676

Gazzonis AL, Villa L, Riehn K, Hamedy A, Minazzi S, Olivieri E, et al. (2018) Occurrence of selected zoonotic food-borne parasites and first molecular identification of Alaria alata in wild boars (Sus scrofa) in Italy. Parasitology Research 117:2207-2215

Gil Molino M, García Sánchez A, Risco Pérez D, Gonçalves Blanco P, Quesada Molina A, Rey Pérez J, et al. (2019) Prevalence of Salmonella spp. in tonsils, mandibular lymph nodes and faeces of wild boar from Spain and genetic relationship between isolates. Transboundary and Emerging Diseases 66:1218-1226

Grantina-Ievina L, Avsejenko J, Cvetkova S, Krastina D, Streikisa M, Steingolde Z, et al. (2018) Seroprevalence of Brucella suis in eastern Latvian wild boars (Sus scrofa). Acta Veterinaria Scandinavica 60:19

Heaton D, Huang S, Shiau R, Casillas S, Straily A, Kong LK, et al. (2018) Trichinellosis outbreak linked to consumption of privately raised raw boar meat - California, 2017. Morbidity and Mortality Weekly Report 67:247-249

Hingston P, Chen J, Dhillon BK, Laing C, Bertelli C, Gannon V, Tasara T, Allen K, Brinkman FSL, Truelstrup Hansen L, Wang S (2017) Genotypes associated with Listeria monocytogenes isolates displaying impaired or enhanced tolerances to cold, salt, acid, or desiccation strees. Frontiers in Microbiology 8:1-20

Hoffmann B, Depner K, Schirrmeier H, Beer M (2006) A universal heterologous internal control system for duplex real-time RT- 
PCR assays used in a detection system for pestiviruses. Journal of Virological Methods 136:200-209

Jemeršic L, Prpic J, Brnic D, Keros T, Pandak N, Đakovic Rode O (2019) Genetic diversity of hepatitis E virus (HEV) strains derived from humans, swine and wild boars in Croatia from 2010 to 2017. BMC Infectious Diseases 19.

Jokelainen P, Näreaho A, Hälli O, Heinonen M, Sukura A (2012) Farmed wild boars exposed to Toxoplasma gondii and Trichinella spp. Veterinary Parasitology 187:323-327

Jones JL, Dubey JP (2012) Foodborne toxoplasmosis. Clinical Infectious Diseases 55:845-851

Kantala T, Maunula L (2018) Hepatitis E virus: Zoonotic and foodborne transmission in developed countries. Future Virology 13:657-670

Kukielka D, Rodriguez-Prieto V, Vicente J, Sánchez-Vizcaíno JM (2016) Constant hepatitis E virus (HEV) circulation in wild boar and red deer in Spain: An increasing concern source of HEV zoonotic transmission. Transboundary and emerging diseases 63:e360-e368

Kärssin A, Velström K, Gómez-Morales MA, Saar T, Jokelainen P, Lassen B (2016) Cross-sectional study of anti-Trichinella antibody prevalence in domestic pigs and hunted wild boars in Estonia. Vector-Borne and Zoonotic Diseases 16:604-610

Laforet CK, Deksne G, Petersen HH, Jokelainen P, Johansen MV, Lassen B (2019) Toxoplasma gondii seroprevalence in extensively farmed wild boars (Sus scrofa) in Denmark. Acta Veterinaria Scandinavica 61:4

López-Goñi I, García-Yoldi D, Marín CM, de Miguel MJ, Barquero-Calvo E, Guzmán-Verri C, et al. (2011) New Bruce-ladder multiplex PCR assay for the biovar typing of Brucella suis and the discrimination of Brucella suis and Brucella canis. Veterinary Microbiology 154:152-155

Lorencova A, Babak V, Lamka J (2016) Serological prevalence of enteropathogenic Yersinia spp. in pigs and wild boars from different production systems in the Moravian region. Czech Republic. Foodborne Pathogens and Disease 13:275-279

Mailles A, Ogielska M, Kemiche F, Garin-Bastuji B, Brieu N, Burnusus Z, et al. (2017) Brucella suis biovar 2 infection in humans in France: Emerging infection or better recognition? Epidemiology and Infection 145:2711-2716

Markov N, Pankova N, Morelle K (2019) Where winter rules: Modeling wild boar distribution in its north-eastern range. Science of the Total Environment 687:1055-1064

Massei G, Kindberg J, Licoppe A, Gačić D, Šprem N, Kamler J, Baubet E, Hohmann U, Monaco A, Ozolinšs J (2015) Wild boars populations up, numbers of hunters down? A review of trends and implications for Europe. Pest Management Science 71:492500.

Mazzei M, Nardini R, Verin R, Forzan M, Poli A, Tolari F (2015) Serologic and molecular survey for hepatitis E virus in wild boar (Sus scrofa) in Central Italy. New Microbes and New Infections 7:41-47

Meier RK, Ruiz-Fons F, Ryser-Degiorgis M (2015) A picture of trends in Aujeszky's disease virus exposure in wild boar in the Swiss and European contexts. BMC Veterinary Research 11:277

Messiaen P, Forier A, Vanderschueren S, Theunissen C, Nijs J, van Esbroeck M, et al. (2016) Outbreak of trichinellosis related to eating imported wild boar meat, Belgium, 2014. Eurosurveillance 21:30341

Muñoz PM, Mick V, Sacchini L, Janowicz A, de Miguel MJ, Cherfa M, et al. (2019) Phylogeography and epidemiology of
Brucella suis biovar 2 in wildlife and domestic swine. Veterinary Microbiology 233:68-77

Nesbakken T, Eckner Røtterud O-J (2008) The effect of blast chilling on occurrence of human pathogenic Yersinia enterocolitica compared to Campylobacter spp. and numbers of hygienic indicators on pig carcasses. International Journal of Food Microbiology 123:130-133

Noeckler K, Pozio E, van der Giessen J, Hill DE, Gamble HR (2019) International Commission on Trichinellosis: Recommendations on post-harvest control of Trichinella in food animals. Food and Waterborne Parasitology 12:e0041

Oksanen A, Interisano M, Isomursu M, Heikkinen P, Tonanzi D, Oivanen L, et al. (2018) Trichinella spiralis prevalence among wildlife of a boreal region rapidly reduced in the absence of spillover from the domestic cycle. Veterinary Parasitology 262:15

Peruzy MF, Murru N, Yu Z, Kerkhof P-, Neola B, Joossens M, et al. (2019) Assessment of microbial communities on freshly killed wild boar meat by MALDI-TOF MS and 16S rRNA amplicon sequencing. International Journal of Food Microbiology 301:51-60

Postel A, Austermann-Busch S, Petrov A, Moennig V, Becher P (2018) Epidemiology, diagnosis and control of classical swine fever: Recent developments and future challenges. Transboundary and Emerging Diseases 65:248-261

Racka K, Bártová E, Budíková M, Vodrážka P (2015) Survey of Toxoplasma gondii antibodies in meat juice of wild boar (Sus scrofa) in several districts of the Czech Republic. Annals of Agricultural and Environmental Medicine 22:231-235

Reinhardt M, Hammerl JA, Kunz K, Barac A, Nöckler K, Hertwig S (2018) Yersinia pseudotuberculosis prevalence and diversity in wild boars in northeast Germany. Applied and Environmental Microbiology 84:e0067-e118

Reiterová K, Špilovská S, Blanarová L, Derdáková M, Cobádiová A, Hisira V (2016) Wild boar (Sus scrofa) - Reservoir host of Toxoplasma gondii, Neospora caninum and Anaplasma phagocytophilum in Slovakia. Acta Parasitologica 61:255-260

Sannö A, Aspán A, Hestvik G, Jacobson M (2014) Presence of Salmonella spp., Yersinia enterocolitica, Yersinia pseudotuberculosis and Escherichia coli O157:H7 in wild boars. Epidemiology and Infection 142:2542-2547

Sannö A, Rosendal T, Aspán A, Backhans A, Jacobson M (2018) Distribution of enteropathogenic Yersinia spp. and Salmonella spp. in the Swedish wild boar population, and assessment of risk factors that may affect their prevalence .Acta Veterinaria Scandinavica 60:40.

Santoro M, Viscardi M, Sgroi G, D’Alessio ND, Veneziano V, Pellicano R, et al. (2019) Real-time PCR detection of Toxoplasma gondii in tissue samples of wild boars (Sus scrofa) from southern Italy reveals high prevalence and parasite load. Parasites and Vectors 12:335

Sauvala M, Laaksonen S, Laukkanen-Ninios R, Jalava K, Stephan R, Fredriksson-Ahomaa M (2019) Microbial contamination of moose (Alces alces) and white-tailed deer (Odocoileus virginianus) carcasses harvested by hunters. Food Microbiology 78:8288

Silva J, Leite D, Fernandes M, Mena C, Gibbs PA, Teixeira P (2011) Campylobacter spp. as a foodborne pathogen: a review. Frontiers in Microbiology 2:1-12

Spancerniene U, Buitkuviene J, Grigas J, Pampariene I, Salomskas A, Cepuliene R, et al. (2016) Seroprevalence of hepatitis E virus 
in Lithuanian domestic pigs and wildlife. Acta Veterinaria Brno 85:319-327

Vajas P, Calenge C, Richard E, Fattebert J, Rousset C, Saïd S, et al. (2020) Many, large and early: Hunting pressure on wild boar relates to simple metrics of hunting effort. Science of the Total Environment 698:134251

Van De N, Nga VT, Dorny P, Trung NV, Minh PN, Dung DT, et al. (2015) Trichinellosis in Vietnam. American Journal of Tropical Medicine and Hygiene 92:1265-1270

von Essen E (2019) How wild boar hunting is becoming a battleground. Leisure Sciences 1-18.

Wacheck S, Fredriksson-Ahomaa M, König M, Stolle A, Stephan R (2010) Wild boars as an important reservoir for foodborne pathogens. Foodborne Pathogens and Disease 7:307-312
Wallander C, Frössling J, Vågsholm I, Uggla A, Lundén A (2015) Toxoplasma gondii seroprevalence in wild boars (Sus scrofa) in Sweden and evaluation of ELISA test performance. Epidemiology and Infection 143:1913-1921

Wang H, Castillo-Contreras R, Saguti F, López-Olvera JR, Karlsson M, Mentaberre G, et al. (2019) Genetically similar hepatitis $\mathrm{E}$ virus strains infect both humans and wild boars in the Barcelona area, Spain, and Sweden. Transboundary and Emerging Diseases 66:978-985

Wernike K, Beer M, Freuling CM, Klupp B, Mettenleiter TC, Müller T, Hoffmann G (2014) Molecular double-check strategy for identification and characterisation of suid herpesvirus 1 . Journal of Virological Methods 209:110-115 